\title{
UTILIZATION OF GGBS IN SMART DYNAMIC CONCRETE TO CONSTRUCT SUSTAINABLE AND DURABLE TALL STRUCTURE A CASE STUDY ON SOBHA INDHRAPRASTHA, BENGALURU, INDIA
}

\author{
Yogananda.M.V ${ }^{1}$, Manjunatha L.R ${ }^{2}, V_{\text {ishwanath Kallappa }}{ }^{3}$, Madhukar.H.M $^{4}$, Sandhya Anvekar $^{5}$ \\ ${ }^{1}$ Concrete Technologist, Technical Services, JSW Cement ltd, Karnataka, India \\ ${ }^{2}$ PhD Research Scholar,Bharatiyar University, R\&D Centre, DGM-JSW Cement \\ ${ }^{3}$ Concrete Technologist, Technical Services, JSW Cement ltd, Karnataka, India \\ ${ }^{4}$ Concrete Technologist, Technical Services, Sobha Ltd, Karnataka, India \\ ${ }^{5}$ Professor, VTU, Bengaluru, India
}

\begin{abstract}
From past few decades migration of humans from rural to urban areas has become a global phenomena and it has created pressure on concerned authorities for need for sustainable housing developments. This is because cities offer substantial reasons to keep coming back, such as jobs, entertainment, and amenities etc. Dense urban areas can be an equally viable and socially sustainable habitat if resources management is done on need basis. Horizontal growth has direct impact on natural resources and available land. In order to overcome the above said problems many countries had resolved by adopting tall structure technology from many of decades. So that area per person have decreased to greaer extent with minimum natural resources and embodied energy. In this case study, Monolithic concrete structure of 37 floors constructed at gopalpura, Bengaluru(India) is under consideration and technology adopted to make the structure durable and sustainable were revealed. Aluminium shuttering technologies were adopted to reduce the construction cycle time and cost. Systematic study is done to develop the Smart Dynamic Concrete by partially replacing ordinary Portland cement by Ground granulated blast furnace slag (GGBS)without compromising fresh and hardened properties of concrete and cycle time. Results showed that, use of ground granulated blast furnace slag and appropriate quantity of combination of Polycarboxylate ether and Viscocity Modifying agents enhances the flowable property and long-term strength of concrete.
\end{abstract}

Keywords: Smart Dynamic Concrete, Ground Granulated Blast furnace slag, Polycarboxylate ether,

Viscosity-Modifying agents

\section{INTRODUCTION}

\subsection{General}

The most prominent tall buildings are called 'high-rise buildings' in most countries and 'tower blocks' in Britain and some European countries. The terms do not have internationally agreed definitions. However, a high-rise building can be defined as follows

The Mumbai Municipal Corporation (BMC) proposed that any building with a height of $30 \mathrm{~m}$ (nine floors) be categorized as a high rise. This is an increase of $6 \mathrm{~m}$ from the existing definition ( $24 \mathrm{~m}$ or seven floors).

But from the structural point of view it can be defined as the a building that its height will be affected by lateral forces resulting from earthquakes and wind forces to extent that such forces will play a major role in the process of design.

\subsection{Background To Smart Dynamic Concrete}

Self compacting concrete (SCC) undoubtedly been a major advancement in the field of concrete technology. But ready mixed concrete manufacturers are not always recommending the use of SCC has it contains higher content of powder compared to traditional concrete as per Bruno[1] and the sensitivity of SCC to variations in mix proportions can lead to higher production costs. Variations in the moisture content of aggregates, especially of sand, can significantly influence the stability of SCC [2]. To overcome the above said problem Smart dynamic concrete were developed with lesser power content compared to SCC which have following similar benefits as that of SCC.

- Achieves better finish and hence reduction in repair cost/Plastering cost.

- Enables designers to go for complicated profile of shuttering as SDC have flowability and fillability property.

- $\quad$ Speedy and simplifies the concrete placement time.

- $\quad$ Less dependency on man power.

- Cost-efficiency and robustness.

- Reduces noise and associated risks from vibrated concrete.

- Ensures quality construction.

- Comparative savings in SDC over SCC. 


\subsection{Objective of Study}

Following are the main objective of this study

- To develop the engineered concrete that can be able to pump till $112 \mathrm{~m}$ without segregation and bleeding.

- To reduce the cost of concrete by partially replacing mineral admixture and in-turn to achieve the sustainability and durability.

- Developed concrete to be tested for its fresh properties, hardened properties and long term strength.

\section{A CASE STUDY ON SOBHA INDHRAPRASTHA PROJECT}

In order to maintain the speed of construction Aluminium shuttering technology is adopted which reduces the construction cycle time by $15-20 \%$ and cost of concrete by $10-15 \%$. The major challenge of concrete is to pump the concrete till 37 floors against the gravity without compromising the quality of concrete. Many constraints made us to switch to Smart Dynamic Concrete (SDC) from Self Compacting Concrete (SCC) as the desired concrete need to achieve the following main criteria

Excellent Stability and Pumpability: Concrete of density closer to $2400 \mathrm{Kg} / \mathrm{m}^{3}$, when pumped against the gravity there will be huge friction arising inside the pipe line between concrete and inner surface of pipe which increases the temperature of concrete in-turn reduces the workability of concrete. To overcome above mentioned problem mineral admixtures such as Ground Granulated Blast Furnace Slag (GGBS) and chemical admixture Master Glenium Sky 8650 which is the combination of Viscocity Modifying Agents (VMA) and Superplasticer of right quantity were used to achieve the desired slump flow, retention and long term strength without compromising the fresh and hardened properties of concrete.

\subsection{Project Background}

Two wings of 37 floors built with $35,000 \mathrm{~m}^{3}$ of Smart Dynamic concrete and $17,000 \mathrm{~m}^{3}$ of Normal concrete which includes different grades of concrete such as M7.5, M25, M30, M35, M40 and M50.

\subsection{Project Challenges and Customer Requirement}

- Demoulding of vertical members within 24 hours.

- Target strength is $50 \%$ within 3 days at $50 \%$ replacement of OPC 53 by GGBS.

- $\quad$ Minimum slump flow of $650 \mathrm{~mm}$ at discharge point.

- Good surface finish in order to avoid plastering/repair after demoulding.

- No external equipment is allowed to compact the concrete as it creates noise during dark hours.

- Concrete to be pumped to $112 \mathrm{~m}$ height from ground against the gravity with available pump.

\section{INGREDIENTS OF CONCRETE}

In the beginning of the project, trials were carried for different grades of concrete with various combination of Ordinary Portland cement-GGBS, Coarse aggregate-Fine aggregate, $20 \mathrm{~mm}$ aggregate $-12 \mathrm{~mm}$ down size aggregate by keeping Cementitious content and water - Cementitious ratio as constant. In order to improve the workability of concrete chemical admixture of different family were tried such as super plasticiser of Napthalene based and Poly Carboxyl Ether based were studied for its fresh and hardened properties of concrete which is not upto the desired level. Hence, PCE+ VMA based super plasticiser (2 in 1 admixture) were tried even though it increases the cubic metre cost of the project. But, the savings and benefits were consistently drawn down by decreasing the manpower, equipment, energy and repair costs without sacrificing the quality of construction and durability. Ingredients details were explained in below mentioned paragraph.

Cement: Ordinary Portland cement 53 grade which meets the all the requirements of IS: 12269-1987 is used.

Mineral Admixture: Ground Granulated Blast Furnace Slag is used in all grades of concrete and it meets the requirement of BS 6699:1992. Minimum 50\% replacement is done for cement in all grades of concrete as it helps in resisting sulphate and chloride attack effectively [3].

Chemical Admixture: Master Glenium sky 8650 (PCE+VMA) - New generation based on second-generation polycarboxylate ether polymer may be used in combination with MasterMatrix 2 for producing Rheodynamic concrete, capable of self compaction without the aid of vibration.

Viscocity Modifying agents: It is a synthetic co-polymer and its molecular structure and properties can be controlled directly at the synthesis stage; therefore the performance is more stable and reliable than conventional viscocity modifying agents. Conventional VMAs can provide variability in performance and hence are less forgiving and harder to control [2].

Coarse Aggregate: Combination of $20 \mathrm{~mm}$ and $12 \mathrm{~mm}$ downsize aggregate is used and it satisfies the requirements of IS: 383-1970.

Manufactured Sand as Fine aggregate: which satisfies the requirement of IS: $383-1970$ is used to make concrete and river sand was not at all used.

Water: Portable water free from chloride, oils, acids, alkalis, sugar, organic matters is used to make concrete and for curing.

\subsection{Approach and Solution}

In order to achieve all the parameters to overcome the problems arrived in normal and Self compacting concrete. Smart dynamic concrete were designed and trials were carried for above mentioned grades of concrete but the 
major quantity of concrete is M25 (SDC) around $30,000 \mathrm{~m}^{3}$. So, developed economical and flowable mix design is clearly mentioned in Table 1, fresh properties is represented in Table 2 and Hardened properties showed in Table 3 were studied and explained in below mentioned paragraph.

Table 1: SDC Mix design

\begin{tabular}{|l|l|l|l|l|l|l|}
\hline $\begin{array}{l}\text { Ingredi } \\
\text { ents }\end{array}$ & $\begin{array}{l}\text { Cem } \\
\text { ent }\end{array}$ & $\begin{array}{l}\text { GG } \\
\text { BS }\end{array}$ & $\begin{array}{l}\text { Wat } \\
\text { er }\end{array}$ & $\begin{array}{l}\text { M- } \\
\text { Sa } \\
\text { nd }\end{array}$ & $\begin{array}{l}\text { Coars } \\
\text { aggre } \\
\text { gate } \\
\mathbf{( 2 0 m} \\
\text { m) }\end{array}$ & $\begin{array}{l}\text { Coars } \\
\text { e } \\
\text { aggre } \\
\text { gate } \\
\mathbf{( 1 2 . 5} \\
\text { mm) }\end{array}$ \\
\hline $\begin{array}{l}\text { Quanti } \\
\text { ty in } \\
\text { Kg/m }\end{array}$ & 200 & 200 & 184 & $\begin{array}{l}95 \\
0\end{array}$ & 210 & 650 \\
\hline
\end{tabular}

\section{RESULTS AND DISCUSSION}

Mock-up trials were carried out in order to finalise the best combination of ingredients without compromising the plastic and hardened parameters of concrete. For the below mentioned concrete design $0.46 \mathrm{w} / \mathrm{c}$ ratio and chemical admixture of 2.4 to 3.2 litres per cubic metre is maintained. From Table no 2, we can conclude that, at optimum dosage of chemical admixtures around 0.6 to $0.8 \%$ flow reached around $650 \mathrm{~mm}$ at the point of discharge at $0_{\min }$ and further reduced at an interval of every $30 \mathrm{~min}$ till $120 \mathrm{~min}$. Above flow is sufficient to pump the concrete in Aluminium form work without vibration with minimum man power. Mix was cohesive with no visual signs of segregation and bleeding. And also from the table, we can observe the slump flow retention from $0_{\min }$ till $120 \mathrm{~min}$ was appreciable. This is mainly due to formation of flexible glue which maintains the cement and fine aggregate particles in suspension. This mechanism allows the formation of a stable concrete paste even with less fine particles, in a very fluid system.

Table 2: SDC slump flow and retention

\begin{tabular}{|l|l|l|l|l|l|}
\hline $\begin{array}{l}\text { Time } \\
\text { elapsed } \\
\text { in Min }\end{array}$ & 0 & 30 & 60 & 90 & 120 \\
\hline $\begin{array}{l}\text { Slump } \\
\text { flow in } \\
\text { mm }\end{array}$ & 650 & 640 & 630 & 620 & 560 \\
\hline
\end{tabular}

After 28 days curing, cubes were kept to study long term strength at 56 days, 90 days and 120 days. From, Table no 3 and Figure 1, we can conclude that, M25 Smart dynamic concrete with 50\% GGBS and 50\% OPC 53 shows increased strength starting from 3 days till 120days. This is because of both hydration and pozzolanic reaction and at the sam etime GGBS helps in pore refinement and grain refinement. After reaching appreciable strength, design was finalised and adopted throughout the project with minor corrections in moisture content and absorption of water for Aggregates. Figure 2 shows the finished concrete structure.
Table 3: Long term strength-M25 Grade SDC

\begin{tabular}{|l|l|l|l|l|l|l|}
\hline $\begin{array}{l}\text { Age in } \\
\text { days }\end{array}$ & 3 & 7 & 28 & 56 & 90 & 120 \\
\hline $\begin{array}{l}\text { Mean } \\
\text { compressi } \\
\begin{array}{l}\text { ve strength } \\
\text { in Mpa }\end{array}\end{array}$ & 17.0 & 23.9 & 39.8 & 53.0 & 54.1 & 56.2 \\
& 6 & 4 & 3 & 2 & 1 \\
\hline
\end{tabular}

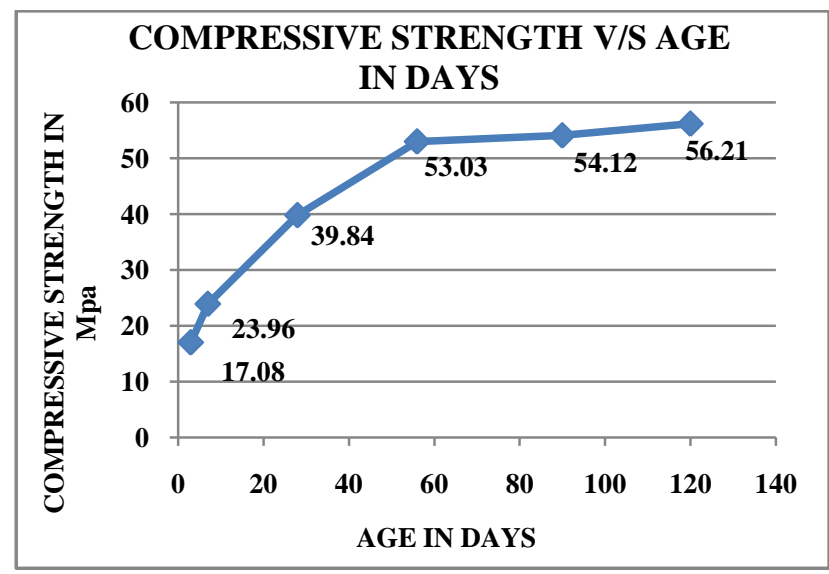

Figure 1: Long-term strength trend

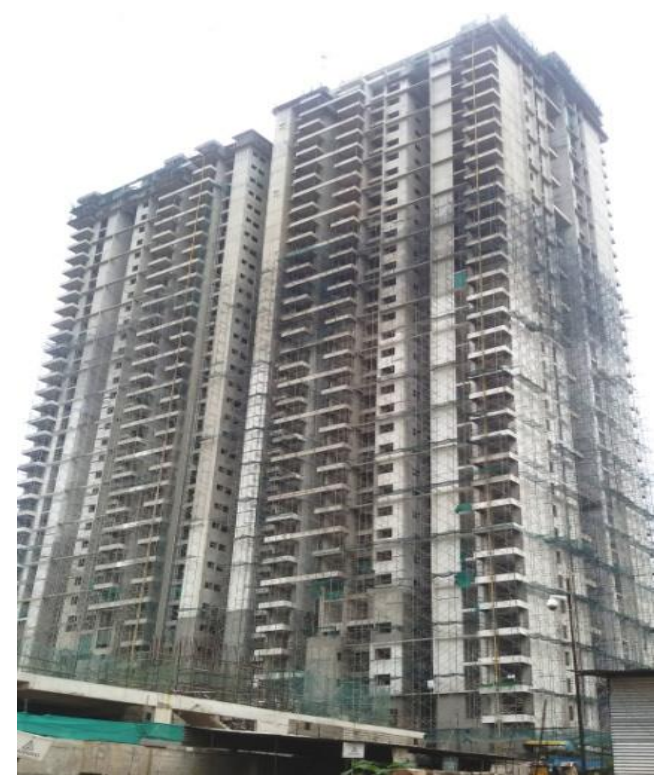

Figure 2: Finished concrete structure

\section{CONCLUSION}

[1]. An innovative concept of utilizing chemical and mineral admixtures to make robust, stable and cohesive concrete with self compacting properties despite relatively low fines content and cost.

[2]. Even with minor variations in materials and mix proportions using of appropriate admixture and quantity maintains the rheology, anti-segregation, cohesive and stable properties of concrete.

[3]. Use of GGBS in SDC reduces carbon footprint, cost per unit and enhances long-term strength, durability and finishability.

[4]. SDC is capable to satisfy all the requirements of 
contactors as it consumes lower powder content, less man power and equipments with minimum construction cycle.

\section{REFERENCES}

[1]. Bruno D"Souza and Hironobu yamamiya "Applications of Smart Dynamic Concrete", Third International conference on sustainable Materials Technologies.

[2]. Ramisetti swamy, M.V Ratnam and Rangaraju “ Effect of Mineral admixtures on properties of self compacting concrete", International journal for Innovative Research in Science \& Technology, Volume 1, Issuue 11, April 2015.

[3]. Salihuddin Radin sumadi etal " Capability of GGBS concrete exposed to sea water", Malaysian Science and Technology Congress, Oct 1999.

[4]. Recommendation for Self-compacting concrete Japan Society of Civil Engineers, Tokyo, Japan, August 1999

[5]. A new viscosity modifying agent (VMC) for low fines Self-consolidating concrete.

[6]. Wallevik, O.H.,'Rheology- A Scientific Approach to develop Self-compacting concrete', 3 rd International Symposium on Self-compacting concrete, Rilem, Reykjavik, Iceland, August 2003

\section{BIOGRAPHIES}

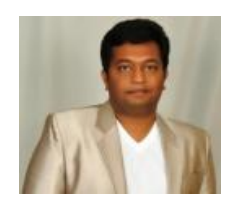

Er.Yogananda.M.V,

Concrete Technologist, JSW Cements Ltd,

Bengaluru.

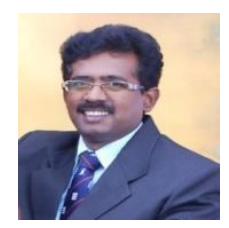

Er. Manjunatha.L.R

Research Scholar,Bharatiyar University ,R\& D Centre.

DGM, Sales\& Marketing,

JSW Cements Ltd,

Bengaluru.

Er. Viswanath K Dalwai

Concrete Technologist,

JSW Cements Ltd,

Bengaluru.

Er.Madhukar.H.M,

Asst Manager,QA/QC,

Sobha Ltd,

Bengaluru. 